\title{
Yield and Quality of Forage Oat (Avena sativa L.) Cultivars as Affected by Seed Inoculation with Nitrogenous Strains
}

\author{
Muhammad Saleem, M. Shahid Ibni Zamir*, Ihtishamul Haq, M. Zahid Irshad, \\ M. Kamran Khan, M. Asim, Qamaruz Zaman, Ihtisham Ali, Aman Khan, Saeedur Rehman \\ Department of Agronomy, University of Agriculture, Faisalabad, Pakistan \\ Email: ibnizamir@uaf.edu.pk, rraoihtisham@gmail.com
}

Received 22 July 2015; accepted 18 December 2015; published 24 December 2015

Copyright (C) 2015 by authors and Scientific Research Publishing Inc.

This work is licensed under the Creative Commons Attribution International License (CC BY). http://creativecommons.org/licenses/by/4.0/

(c) (i) Open Access

\section{Abstract}

Nitrogen availability can be enhanced with the application of nitrogen fixing bacteria and it may be helpful in increasing forage yield and improving quality of oat. Therefore, a field trial to evaluate the effect of seed inoculation with nitrogen fixing bacteria on forage yield and quality of oat was carried out at Agronomic Research Area, University of Agriculture, Faisalabad during Rabi season 2013-14. The experiment was laid out in Randomized Complete Block Design (RCBD) with factorial arrangements using three replications. The experiment was comprised of two integrated approaches. The first approach was oat cultivars consisting of four treatments, $V_{1}$ (AVON), $V_{2}$ (S-2000), $V_{3}$ (S-2011) and $V_{4}$ (PD2LV65) and the second approach was seed inoculation consisting of three treatments, $S_{0}$ (control), $S_{1}$ (Azotobacter spp.), $S_{2}$ (Azospirillum spp.). Fisher's analysis of variance technique was used for statistically interpretation of data by using least significant difference (LSD) test at 5\% level of probability. Nitrogen fixing bacteria significantly affect the germination count $\left(\mathrm{m}^{-2}\right)$, plant height $(\mathrm{cm})$, number of tillers $\left(\mathrm{m}^{-2}\right)$, number of leaves per tiller, leaf area per tiller $\left(\mathrm{cm}^{2}\right)$, green forage yield $\left(\mathrm{t} \cdot \mathrm{ha}^{-1}\right)$ and dry matter yield $\left(\mathrm{t} \mathrm{ha} \mathrm{a}^{-1}\right)$. The maximum green forage yield (85.2 tha $\left.\mathrm{a}^{-1}\right)$, dry matter yield $\left(14.1 \mathrm{t} \cdot \mathrm{ha}^{-1}\right)$ and crude protein $(11.5 \%)$ were recorded where Azotobacter inoculation was applied. The interaction between cultivars and nitrogenous strains was significant for green forage yield $\left(t \cdot h a^{-1}\right)$, dry matter yield $\left(t \cdot h a^{-1}\right)$ and crude protein (\%). Conclusion showed that cultivar Sargodha-2011 which was inoculated with Azotobacter spp. gave higher forage yield of good quality.

\section{Keywords}

Oat Cultivars, Nitrogenous Strains, Quality and Forage Yield

\footnotetext{
${ }^{*}$ Corresponding author.
}

How to cite this paper: Saleem, M., Zamir, M.S.I., Haq, I., Irshad, M.Z., Khan, M.K., Asim, M., Zaman, Q., Ali, I., Khan, A. and Rehman, S. (2015) Yield and Quality of Forage Oat (Avena sativa L.) Cultivars as Affected by Seed Inoculation with Nitrogenous Strains. American Journal of Plant Sciences, 6, 3251-3259. http://dx.doi.org/10.4236/ajps.2015.619316 


\section{Introduction}

Oat (Avena sativa L.) is a cereal forage crop which belongs to poaceae family. In Pakistan it is cultivated in irrigated and rainfed conditions. It contains large amount of digestible crude protein, total digestible nutrients (TDN), vitamin B1, minerals and fat. It is favorite feed of animals and its straw is soft and superior to wheat and barley. The oat grain is valuable feed for dairy cows, horses, poultry and young breeding animals [1]. The existing forage supply in Pakistan is $2 / 3^{\text {rd }}$ of actual requirement [2]. The animals in Pakistan are usually underfed resulting unsatisfactory production of animals. Animals are facing $40 \%$ to $60 \%$ deficiency in energy and protein respectively [3]. But forage yield of our native cultivars is so low that it is insufficient to fulfill the requirements of livestock. Therefore, both quality and quantity of forage crops still needs to be improved up to required level. Ideal forage should have high yield of dry matter, high crude protein content and digestibility but low percentage of crude fiber [4].

There are many factors responsible for the low yield, but the use of traditional or low yielding cultivars and poor adaptation of management practices is of main importance [5]. The improved cultivars of oat can feed double number of animals per unit area as the traditional forage crops in the region due to having three-fold higher yield potential of green forage [6]. With the introduction of newly evolved high yielding cultivars, oat has been recognized by the farmer a vital winter forage for filling gap of forage [7] among different possibilities to fulfill the forage shortage as happens in our country, the most pragmatic option is the growing of those cultivars which have high forage yield production [8]. [9] compared four oat cultivars for protein value and reported significant differences among cultivars for protein values.

Bio-fertilizers comprise of microorganisms which are capable to nutrients mobilization by using biological process [10]. In agriculture bio-fertilizers become valuable because various biotic and abiotic factors influence crop growth, yield and nitrogen fixing bacteria especially Azotobacter and Azospirillum increased yield in cereals [11]. Atmospheric nitrogen fixation through seed inoculation with Azotobacter and Azospirillum exerts positive effect on crop growth and yield. [12] [13] reported that in Pakistan about 52\% - 54\% less forage is produced than actual requirement. Due to increasing cost of fertilizers day by day in Pakistan, small land holder farmer's community could not fulfill the proper demand for lacking nutrients in our soils. To solve this problem we have to use bio-fertilizers, organic and inorganic sources or their combinations to meet the demand of oat forage crop for better nourishment of animals.

The use of chemical and inorganic fertilizer is increasing in this modern era which deteriorates our soil health and also pollutes our environment, so bio-fertilizers or organic manures would be a viable option to sustain our production system [14].

Bacteria present in sufficient amount in rhizosphere enhance the growth and yield of interested crop as reported by [15] [16] reported that combined use of inorganic $\mathrm{N}$ fertilizer (Urea) with bio-fertilizer (Azotobacter and Azospirillum) on yield, yield attributes and harvest index of wheat. All treatments considerably affected plant height $(\mathrm{cm})$, leaf area $\left(\mathrm{cm}^{2}\right)$, number of tillers, straw yields and harvest index. The effect of Azotobacter chroococcum on soil nitrogen balance has been reported on different plant species such as forage oat (Avena sativa L.) by [17] and many other crops. Previous studies reported that when seeds were inoculated with Azotobacter strains, Indole acetic acid (IAA) was produced as concluded by [18] and these hormonal substances if presented in rhizosphere would affect the adjacent plants by production auxins, gibberellic acid and cytokinins as reported by [19].

Azotobacter and Azospirillum are potential bio-fertilizers and are capable to contribute nitrogen to a number of non-leguminous crops and can help us to increase quality and yield of forage crops without increased application of chemical fertilizers that pollute the environment.

\section{Materials and Methods}

\subsection{Experimental Materials, Design and Treatments}

A field trial to evaluate the effect of seed inoculation with nitrogenous strains on forage yield and quality of oat was carried out at Agronomic Research Area, University of Agriculture, Faisalabad during Rabi season 2013-14. The experiment was laid out in Randomized Complete Block Design with factorial arrangements using three replications. The net plot size was $2.4 \mathrm{~m} \times 6 \mathrm{~m}$. The experiment was comprised of two integrated approaches. First approach was oat cultivars consisting of four treatments, $V_{1}$ (AVON), $V_{2}(S-2000), V_{3}(S-2011)$ and $V_{4}$ (PD2LV65) and second approach was seed inoculation consisting of three treatments, $\mathrm{S}_{0}$ (control), $\mathrm{S}_{1}$ (Azoto- 
bacterspp.), $\mathrm{S}_{2}$ (Azospirillum spp.). Oat cultivars and nitrogenous strains culture were obtained from Ayub Agricultural Research Institute, Faisalabad, Punjab, Pakistan. Crop was sown with the recommended seed rate of $75 \mathrm{~kg} \cdot \mathrm{ha}^{-1}$ on December $10^{\text {th }}, 2013$ by using single row hand drill in $30 \mathrm{~cm}$ apart rows. The phosphorus at the rate of $60 \mathrm{~kg} \cdot \mathrm{ha}^{-1}$ was applied in the form of Di-ammoniumphosphate (DAP) was applied at sowing time. The nitrogen at the rate of $80 \mathrm{~kg} \cdot \mathrm{ha}^{-1}$ was applied in the form of urea. Half dose of nitrogen was applied at sowing time while remaining half dose was applied with first irrigation. The total of three irrigations was given to the crop from sowing to harvest. All other agronomic practices (irrigation, weeds control, insect pest control and harvesting etc.) were kept constant for all the treatments.

\subsection{Experimental Site}

The experiment was carried out at the Agronomic Research Area, University of Agriculture, Faisalabad during the year 2013-14. Experimental site lies between 30.35 - $41.47 \mathrm{~N}$ latitude and 72.08 - $73.40 \mathrm{E}$ longitude at an elevation of $184.4 \mathrm{~m}$ above sea level.

\subsection{Data Collection}

The crop was harvested 90 days after sowing when 50\% of flowering had been occurred. The data on yield and yield component like (number of tillers, plant height, leaf area per tiller, number of leaves per tiller, leaf to stem ratio, green forage yield and dry matter yield) While quality parameters (dry matter percentage, crude protein percentage, total ash percentage and ether extractable fat percentage) both were recorded by standard procedure.

\subsection{Crude Protein}

\section{Principle}

"Conversion of the nitrogenous compounds of the sample into ammonium sulphate $\left(\mathrm{NH}_{4}\right)_{2} \mathrm{SO}_{4}$ by boiling with sulphuric acid $\left(\mathrm{H}_{2} \mathrm{SO}_{4}\right)$ and subsequent decomposition of ammonium sulphate with fixed alkali $(40 \% \mathrm{NaOH})$ and collection of ammonia in an acid solution was titrated against an acid of known strength and $\mathrm{N}$ of the sample was computed."

Oven dried $1.0 \mathrm{~g}$ of plant material, 25 - $30 \mathrm{ml}$ of commercial $\mathrm{H}_{2} \mathrm{SO}_{4}$ and $5 \mathrm{~g}$ of digestion mixture $\left(\mathrm{K}_{2} \mathrm{SO}_{4}\right.$ : $\mathrm{FeSO}_{4}: \mathrm{CuSO}_{4}=85: 05: 10$ ) was added and then digested the plant material in the digestion chamber until transparent or colourless content appeared ( 3 - 5 hours), cooled and made the volume up to $250 \mathrm{ml}$ and $10 \mathrm{ml}$ was taken from this for distillation of each sample. Nitrogen evolved as ammonia was collected in a receiving flask containing 4\% boric acid solution and mixed indicator (methyl red). Its colour was changed to white from pink and then it was titrated against standard $(0.1 \mathrm{~N}) \mathrm{H}_{2} \mathrm{SO}_{4}$ up to golden yellowish colour (end point). The volume of acid used was recorded and $\mathrm{N} \%$ was calculated by the formula given below.

$$
\mathrm{N} \%=\frac{\text { Vol. of N } / 10 \mathrm{H}_{2} \mathrm{SO}_{4} \times \text { Vol. of Sample Solution } \times 0.0014}{\text { Wt. of Sample } \times \text { Vol. of Sample Solution used }} \times 100
$$

The N\% was then multiplied by 6.25 to get crude protein percentage.

\subsection{Statistical Analysis}

Fisher's analysis of variance technique was used for statistically interpretation of data by using least significant difference (LSD) test at 5\% level of probability.

\section{Results and Discussion}

\subsection{Number of Tillers $\left(\mathrm{m}^{-2}\right)$}

Number of tillers $\mathrm{m}^{-2}$ is an important yield contributing parameter. Higher number of tillers higher will be the fodder yield $\left(\mathrm{t} \cdot \mathrm{h} \mathrm{a}^{-1}\right)$. However, the data in Table 1 shows that the highly significant differences were observed among the cultivars for the number of tillers $\left(\mathrm{m}^{-2}\right)$. Significantly maximum numbers of tillers were recorded in cultivar Sargodha-2011 and it was followed by Avon; however in rest of the cases no of tillers were substantially decreased. [20] reported similar results regarding number of tillers $\left(\mathrm{m}^{-2}\right)$. The effect of inoculation with nitrogenous strains (Azotobacter and Azospirillum) on number of tillers $\left(\mathrm{m}^{-2}\right)$ was significant. Maximum number 
Table 1. Agronomic and yield related parameters of oat cultivars as affected by seed inoculation with nitrogenous strains.

\begin{tabular}{|c|c|c|c|c|c|c|c|}
\hline Treatment & $\begin{array}{l}\text { Number of } \\
\text { tillers }\left(\mathrm{m}^{-2}\right)\end{array}$ & $\begin{array}{l}\text { Plant height } \\
\quad(\mathrm{cm})\end{array}$ & $\begin{array}{l}\text { Number of } \\
\text { leaves per } \\
\text { tiller }\end{array}$ & $\begin{array}{l}\text { Leaf area per } \\
\text { tiller }\left(\mathrm{cm}^{2}\right)\end{array}$ & $\begin{array}{l}\text { Leaf to stem } \\
\text { ratio }\end{array}$ & $\begin{array}{l}\text { Green forage } \\
\text { yield }\left(\mathrm{t} \cdot \mathrm{ha}^{-1}\right)\end{array}$ & $\begin{array}{l}\text { Dry forage } \\
\text { yield }\left(\mathrm{t} \cdot \mathrm{ha}^{-1}\right)\end{array}$ \\
\hline \multicolumn{8}{|c|}{ Oat cultivars } \\
\hline $\mathrm{V}_{1}$ & 763.03 B & $141.70 \mathrm{~B}$ & $5.93 \mathrm{~B}$ & 205.11 B & 0.392 B & 67.98 & 10.14 \\
\hline $\mathrm{V}_{2}$ & 700.17 C & 137.31 C & $5.75 \mathrm{~B}$ & 166.47 C & 0.394 B & 65.43 & 9.43 \\
\hline $\mathrm{V}_{3}$ & 790.87 A & $143.97 \mathrm{~A}$ & $6.62 \mathrm{~A}$ & 217.22 A & $0.425 \mathrm{~A}$ & 72.72 & 11.03 \\
\hline $\mathrm{V}_{4}$ & 713.66 C & 132.17 D & $5.37 \mathrm{C}$ & $148.97 \mathrm{D}$ & $0.370 \mathrm{C}$ & 62.38 & 8.47 \\
\hline LSD value & 13.51 & 2.225 & 3.70 & 7.48 & 0.0077 & 1.25 & 0.13 \\
\hline F value & $63.38^{* *}$ & $16.95^{* *}$ & $26.01^{* *}$ & $157.80^{* *}$ & $73.24^{* *}$ & $103.73^{* *}$ & $591.37^{* *}$ \\
\hline \multicolumn{8}{|c|}{ Inoculation } \\
\hline $\mathrm{S}_{\mathrm{o}}$ & $726.19 \mathrm{C}$ & $131.05 \mathrm{C}$ & $5.64 \mathrm{~B}$ & $169.09 \mathrm{C}$ & $0.380 \mathrm{C}$ & 52.18 & 6.67 \\
\hline $\mathrm{S}_{1}$ & $759.80 \mathrm{~A}$ & 146.23 A & $6.17 \mathrm{~A}$ & $198.01 \mathrm{~A}$ & $0.412 \mathrm{~A}$ & 79.85 & 12.7 \\
\hline $\mathrm{S}_{2}$ & 739.81 B & 139.09 B & $5.95 \mathrm{~A}$ & 186.22 B & 0.394 B & 69.36 & 9.94 \\
\hline LSD value & 15.60 & 3.21 & 3.21 & 6.48 & 0.0067 & 1.88 & 0.11 \\
\hline F value & $13.46^{* *}$ & $48.13^{* *}$ & $19.16^{* *}$ & $43.31^{* *}$ & $47.74^{* *}$ & $1411.2^{* *}$ & $6114.2^{* *}$ \\
\hline \multicolumn{8}{|c|}{$\mathrm{V} \times \mathrm{S}$} \\
\hline $\mathrm{V}_{1} \mathrm{~S}_{\mathrm{o}}$ & 746.7 & 133.7 & 5.7 & 185.0 & 0.369 & $51.7 \mathrm{~h}$ & $6.7 \mathrm{j}$ \\
\hline $\mathrm{V}_{2} \mathrm{~S}_{\mathrm{o}}$ & 702.7 & 131.43 & 5.4 & 154.3 & 0.384 & $52.1 \mathrm{~h}$ & $6.1 \mathrm{k}$ \\
\hline $\mathrm{V}_{3} \mathrm{~S}_{\mathrm{o}}$ & 771.9 & 136.1 & 6.1 & 202.2 & 0.408 & $57.9 \mathrm{~g}$ & $8.3 \mathrm{i}$ \\
\hline $\mathrm{V}_{4} \mathrm{~S}_{0}$ & 683.2 & 122.9 & 5.2 & 134.7 & 0.359 & $47 \mathrm{i}$ & 5.41 \\
\hline $\mathrm{V}_{1} \mathrm{~S}_{1}$ & 781.1 & 147.7 & 6.2 & 220.2 & 0.418 & $82.0 \mathrm{~b}$ & $13.4 \mathrm{~b}$ \\
\hline $\mathrm{V}_{2} \mathrm{~S}_{1}$ & 708.8 & 145 & 5.8 & 176.9 & 0.406 & $77.6 \mathrm{c}$ & $12.2 \mathrm{c}$ \\
\hline $\mathrm{V}_{3} \mathrm{~S}_{1}$ & 810.3 & 151.9 & 7.2 & 229.5 & 0.441 & $85.2 \mathrm{a}$ & $14.1 \mathrm{a}$ \\
\hline $\mathrm{V}_{4} \mathrm{~S}_{1}$ & 738.8 & 139 & 5.4 & 165.38 & 0.383 & $74.5 \mathrm{~d}$ & $11 \mathrm{~d}$ \\
\hline $\mathrm{V}_{1} \mathrm{~S}_{2}$ & 761.2 & 143.6 & 5.8 & 210.0 & 0.388 & $70.2 \mathrm{e}$ & $10.2 \mathrm{f}$ \\
\hline $\mathrm{V}_{2} \mathrm{~S}_{2}$ & 688.8 & 135.1 & 6.0 & 168.1 & 0.394 & $66.5 \mathrm{f}$ & $9.9 \mathrm{~g}$ \\
\hline $\mathrm{V}_{3} \mathrm{~S}_{2}$ & 790.2 & 143.8 & 6.5 & 219.9 & 0.424 & $75 \mathrm{~d}$ & $10.5 \mathrm{e}$ \\
\hline $\mathrm{V}_{4} \mathrm{~S}_{2}$ & 718.8 & 133.7 & 5.4 & 146.8 & 0.368 & $65.5 \mathrm{f}$ & $8.9 \mathrm{~h}$ \\
\hline LSD value & $\ldots \ldots$ & $\ldots \ldots$ & $\ldots \ldots$ & $\ldots \ldots$ & $\ldots \ldots$ & 2.18 & 0.23 \\
\hline F value & $1.65^{\mathrm{NS}}$ & $0.66^{\mathrm{NS}}$ & $1.54^{\mathrm{NS}}$ & $0.69^{\mathrm{NS}}$ & $1.84^{\mathrm{NS}}$ & $2.73^{* *}$ & $37.43^{*}$ \\
\hline
\end{tabular}

${ }^{*}=$ Significant at $p \leq 0.05 ;{ }^{* *}=$ Significant at $p \leq 0.01 ; \mathrm{NS}=$ Non-significant; $\mathrm{V}=$ Cultivars; $\mathrm{S}=$ Inoculation; $\mathrm{S}_{0}=$ Control (Un-inoculated); $\mathrm{S}_{1}=\mathrm{Seed}$ treated with Azotobacter spp.; $\mathrm{S}_{2}=$ Seed treated with Azospirillum spp.; $\mathrm{V}_{1}=$ Avon; $\mathrm{V}_{2}=$ Sargodha-2000; $\mathrm{V}_{3}=$ Sargodha-2011; $\mathrm{V}_{4}=$ PD2LV65; Any two means not sharing a letter in common in a row differ significantly at $p \leq 0.05$.

of tillers were recorded where Azotobacter inoculation was applied and the lowest number of tillers were recorded in un-inoculated (control) treatment. The increase in number of tillers with inoculation may be due to the fact that Azotobacter and Azospirillumare nitrogen fixing bacteria which increased nitrogen availability and produced growth hormones which resulted in production of more number of tillers $\left(\mathrm{m}^{-2}\right)$. These results confirm the findings of [21] who reported promoting effect of seed inoculation on number of tillers $\left(\mathrm{m}^{-2}\right)$.

\subsection{Plant Height (cm)}

Plant height is an important growth related parameter which is directly correlated with productivity of plants in 
terms of forage yield. Data regarding plant height in Table 1 shows that significant difference was observed among the cultivars. Significantly maximum number of plant height was recorded in cultivar Sargodha-2011 and the minimum plant height was recorded in cultivar PD2LV65. The variations in plant height between the cultivars might be due to the variations in genetic makeup of crop plants. Significant differences for plant height among the cultivars have also been reported by [22]. The effect of inoculation with nitrogenous strains (Azotobacter and Azospirillum) on plant height was also significant. Statistically maximum plant height was recorded where Azotobacter inoculation was applied and the lowest plant height was recorded in un-inoculated (control) treatment. The reason for increase in plant height in inoculated treatment might be due to secretion of plant growth promoting hormones like auxin, gibberellin and cytokinins which increased the rate of nutrient uptake and increase nitrogen availability [23].

\subsection{Leaf Area per Tiller $\left(\mathrm{cm}^{2}\right)$}

Leaf area is the measure of the size of assimilatory system of plant. Leaf area is produce of leaf length, breadth and leaf number per plant. However, data in Table 1 shows that significant differences were also observed among the cultivars for leaf area per tiller. Significantly maximum leaf area was recorded in the cultivar Sargodha-2011 and the minimum leaf area was recorded in case of PD2LV65 cultivar. The genetic makeup of the cultivars might have been the cause of these variations. Significant differences among the cultivars for leaf area per tiller have also been reported by [24]. The effect of seed inoculation with nitrogenous strains (Azotobacter and Azospirillum) on leaf area per tiller was also significant. Maximum leaf area per tiller was recorded where Azotobacter inoculation was applied and the lowest leaf area per tiller was recorded in un-inoculated (control) treatment. The inoculation of seeds might have enhanced nitrogen fixation which increased the availability of nitrogen, as nitrogen triggers the vegetative growth. Proper light penetration to crop canopy and air circulation helps to increase leaf area. Those treatments which receive more light possess more leaf area. Because of more leaf area it represented that more photosynthates were accumulated and partitioned which ultimately determined final biomass of the crop. These results are in line with those of [25] who reported that bio-fertilizers such as Azotobacter and Azospirillum improved plant growth, number of leaves per tiller and leaf area.

\subsection{Number of Leaves per Tiller}

Total number of leaves play a dynamic role in overall development and growth of the plant because leaves act as the basic factory for food production. However, data in Table 1 shows thatsignificant differences were recorded for number of leaves per tiller among the cultivars. Regarding oat cultivars, statistically maximum number of leaves per tiller was recorded in Sargodha-2011 followed by cultivar Avon and the lowest number of leaves per tiller was recorded in cultivar PD2LV65. Regarding seed inoculation, maximum number of leaves per tiller was recorded where Azotobacter inoculation was applied and followed by Azospirillum with number of leaves per tiller and these two inoculants are statistically at par. Minimum number of leaves per tiller was recorded in control.The variability in number of leaves per plant may be due to secretion of plant growth promoting hormones like auxins, gibberellins and cytokinins and due to appropriate and timely availability of nutrients. As increase or decrease in number of leaves per plant has a direct influence on green forage yield. More number of leaves more will be forage yield and quality. As (Azotobacter and Azospirillum) plays important role in better provision of nitrogen to crop plants which ultimately help to increase vegetative growth and leaves are basic constituent of vegetative growth. These results are in line with those of [25] who reported that bio-fertilizers such as Azotobacter and Azospirillum improved plant growth, number of leaves per tiller and leaf area.

\subsection{Leaf to Stem Ratio}

Cultivars differed significantly regarding the data in Table 1 of leaf to stem ratio. Statistically maximum leaf to stem ratio was recorded in the cultivar Sargodha-2011 and it was followed by Avon and Sargodha-2000, these two cultivars are statistically at par; however in rest of the cases leaf to stem ratio were substantially decreased. The increase in leaf to stem ratio with increase in nitrogen may be attributed to more number of leaves per tiller and more fresh weight of leaves as compared to control. Similar results were also reported by [26]. The effect of inoculation with nitrogenous strains (Azotobacter and Azospirillum) on leaf to stem ratio was significant. Maximum leaf to stem ratio was recorded where Azotobacter inoculation was applied and minimum leaf to stem ratio 
was recorded in (control) un-inoculated treatment. The inoculation might have enhanced nitrogen availability to vegetative parts especially leaves thus increasing the size and fresh weight of leaves which resulted in wider leaf to stem ratio. These results are quite in line to those of [27] who reported significant promoting effect of seed inoculation on leaf to stem ratio of barley used as forage.

\subsection{Green Forage Yield (t·ha ${ }^{-1}$ )}

Green forage yield reveals about the total biomass attained by the plant during its life cycle under prevailing conditions and it has mainly three constituents stalk, pith and grain yield. Data regarding plant height in Table 1 shows that significantly maximum green forage yield was recorded in treatment $\left(\mathrm{V}_{3} \mathrm{~S}_{1}\right)$ where cultivar Sargodha-2011 was inoculated with Azotobacter and it was followed by treatment $\left(\mathrm{V}_{1} \mathrm{~S}_{1}\right)$ where cultivar Avon was inoculated with Azotobacter; however in rest of the cases green forage yield were substantially decreased. The inoculation of seeds might have enhanced nitrogen fixation which increased the availability of nitrogen, as nitrogen triggers the vegetative growth and ultimately increase the green forage yield. These results are also in line with those of [28] who also observed significant increase in plant biomass of maize cultivars with seed inoculation and nitrogen fertilization at recommended dose.

\subsection{Dry Forage Yield (t·ha- $\left.{ }^{-1}\right)$}

Dry forage production is basically a measure of photosynthetic efficiency of assimilatory system in plants. Dried stalk yield refers to the function of maximum nutrients accumulation in plant biomass, the genetic makeup of a crop, soil nutrient status and management strategies. Data regarding dry forage production in Table 1 shows that statistically maximum dry matter yield was recorded in treatment $\left(\mathrm{V}_{3} \mathrm{~S}_{1}\right)$ where cultivar Sargodha-2011 was inoculated with Azotobacter and it was followed by treatment $\left(\mathrm{V}_{1} \mathrm{~S}_{1}\right)$ where cultivar Avon was inoculated with Azotobacter; however in rest of the cases dry matter yield were substantially decreased. It might be due to the fact that growth promoting and nitrogen fixing bacteria increase dry matter yield by increasing nitrogen availability and promoting plant dry matter accumulation in the vegetative parts. These results are in line with those of [29] who reported an increase of $10 \%$ - 15\% in green and dry forage yield of oat through seed inoculation.

\section{Quality Parameters}

\subsection{Dry Matter Percentage}

Highly significant differences were also observed among the cultivars for dry matter \%; However, data in Table 2. Significantly maximum dry matter \% was recorded in the cultivar Sargodha-2011 and it was followed by the cultivar Sargodha-2000; however in rest of the cases dry matter percentage was substantially decreased. These results are in line to those of [30]. These results can be attributed to differences in soil fertility status and genetic makeup of the cultivars. The effect of inoculation with nitrogenous strains (Azotobacter and Azospirillum) was significant. Maximum dry matter \% was recorded where Azotobacter inoculation was applied and it was followed by Azospirillum with \% dry matter. Minimum dry matter \% was recorded in un-inoculated control treatment. It might be due to the fact that growth promoting and nitrogen fixing bacteria increase dry matter yield by increasing nitrogen availability and promoting plant dry matter accumulation in the vegetative parts. These results are in line with those of [29] who reported an increase of $10 \%$ - 15\% in green and dry forage yield of oat through seed inoculation with Azotobacter.

\subsection{Crude Protein Percentage}

Data regarding the crude protein showed that the interaction effect of oat cultivars and inoculation was significant; However, data in Table 2. Maximum crude protein \% was recorded in treatment $\left(\mathrm{V}_{3} \mathrm{~S}_{1}\right)$ where cultivar Sargodha-2011 was inoculated with Azotobacter and it was followed by treatment $\left(\mathrm{V}_{3} \mathrm{~S}_{2}\right)$ where Sargodha-2011was inoculated with Azospirillum with crude protein; however in rest of the cases crude protein were substantially decreased. The increase in protein contents may be attributed to the fact that Azotobacter and Azospirillum are nitrogen fixing bacteria which may have increased nitrogen availability and nitrogen is the basic constituent of amino acids that form protein. These results are similar to those of [30] who reported that seed inoculation of forage oat with Azotobacter increased the protein yield by 7\% over un-inoculated (control). 
Table 2. Forage quality parameters of oat cultivars as affected by seed inoculation with nitrogenous strains.

\begin{tabular}{|c|c|c|c|c|}
\hline Treatment & Dry matter\% & Crude protein \% & Total ash \% & Fat content \% \\
\hline \multicolumn{5}{|c|}{ Oat cultivars } \\
\hline V1 & $13.39 \mathrm{C}$ & 9.09 & $12.33 \mathrm{~B}$ & $4.13 \mathrm{~B}$ \\
\hline V2 & $15.96 \mathrm{~B}$ & 8.86 & $10.98 \mathrm{C}$ & $3.80 \mathrm{C}$ \\
\hline V3 & $16.90 \mathrm{~A}$ & 10.38 & $13.34 \mathrm{~A}$ & $4.50 \mathrm{~A}$ \\
\hline V4 & $13.99 \mathrm{C}$ & 7.81 & $9.38 \mathrm{D}$ & $3.42 \mathrm{D}$ \\
\hline LSD value & 0.81 & & 0.99 & 0.29 \\
\hline F value & $24.19^{* *}$ & & $13.76^{* *}$ & $21.87^{* *}$ \\
\hline \multicolumn{5}{|c|}{ Inoculation } \\
\hline So & $14.22 \mathrm{C}$ & 7.59 & $9.26 \mathrm{C}$ & $3.39 \mathrm{C}$ \\
\hline S1 & $16.34 \mathrm{~A}$ & 9.95 & $13.03 \mathrm{~A}$ & $4.44 \mathrm{~A}$ \\
\hline S2 & $15.38 \mathrm{~B}$ & 9.56 & $11.74 \mathrm{~B}$ & $4.05 \mathrm{~B}$ \\
\hline LSD value & 0.70 & & 1.20 & 0.25 \\
\hline F value & $19.67^{* *}$ & & $12.91^{* *}$ & $38.22^{* *}$ \\
\hline \multicolumn{5}{|c|}{$\mathrm{V} \times \mathrm{S}$} \\
\hline$V_{1}$ So & 14.2 & $7.4 \mathrm{~h}$ & 9.6 & 3.5 \\
\hline V2So & 13.9 & $7.3 \mathrm{~h}$ & 9.5 & 3.2 \\
\hline V3So & 15.6 & $8.7 \mathrm{f}$ & 11.2 & 3.8 \\
\hline V4So & 13.0 & $6.8 \mathrm{i}$ & 8.7 & 2.9 \\
\hline V1S1 & 15.4 & $10.1 \mathrm{c}$ & 14.2 & 4.7 \\
\hline V2S1 & 17.1 & $9.7 \mathrm{~d}$ & 12.4 & 4.2 \\
\hline V3S1 & 17.8 & $11.5 \mathrm{a}$ & 15.1 & 5.1 \\
\hline V4S1 & 14.9 & $8.3 \mathrm{~g}$ & 10.4 & 3.8 \\
\hline V1S2 & 13.5 & $9.6 \mathrm{~d}$ & 13.2 & 4.1 \\
\hline V2S2 & 16.8 & $9.5 \mathrm{e}$ & 11.0 & 3.9 \\
\hline V3S2 & 17.2 & $10.8 \mathrm{~b}$ & 13.7 & 4.6 \\
\hline V4S2 & 13.9 & $8.2 \mathrm{~g}$ & 9.0 & 3.4 \\
\hline LSD value & & 0.17 & & \\
\hline F value & $2.54 \mathrm{NS}$ & $27.47^{* *}$ & $0.54 \mathrm{NS}$ & $0.35 \mathrm{NS}$ \\
\hline
\end{tabular}

\footnotetext{
${ }^{*}=$ Significant at $p \leq 0.05 ;{ }^{* *}=$ Significant at $p \leq 0.01 ; \mathrm{NS}=$ Non-significant; $\mathrm{V}=$ Cultivars; $\mathrm{S}=$ Inoculation; $\mathrm{S}_{0}=$ Control (Un-inoculated); $\mathrm{S}_{1}=$ Seed treated with Azotobacter spp.; $\mathrm{S}_{2}=$ Seed treated with Azospirillum spp.; $\mathrm{V}_{1}=$ Avon; $\mathrm{V}_{2}=$ Sargodha-2000; $\mathrm{V}_{3}=$ Sargodha-2011; $\mathrm{V}_{4}=$ PD2LV65; Any two means not sharing a letter in common in a row differ significantly at $p \leq 0.05$.
}

\subsection{Total Ash Percentage}

Cultivars differed significantly regarding ash contents; However, data in Table 2. Significantly higher total ash was recorded in cultivar Sargodha-2011. It was followed by the cultivar Avon with of total ash. Minimum total ash was recorded in cultivar PD2LV65. [31] also observed significant differences among the cultivars for ash contents. The Effect of inoculation with nitrogenous strains (Azotobacter and Azospirillum) on ash contents was significant. Statistically maximum total ash was recorded where Azotobacter inoculation was applied and it was followed by Azospirillum with total ash. Minimum total ash was recorded in un-inoculated control treatment. The increase in total ash percentage may be attributed to the fact that Azotobacter and Azospirillum increased the nitrogen availability which may have enhanced the nutrient uptake from the soil which in turn to increase the total ash contents. These results are in line with those of [32] who reported that double inoculation of maize with 
Azotobacter and Azospirillum yielded more ash content than control treatment.

\subsection{Ether Extractable Fat Percentage}

Cultivars differed significantly regarding ether extractable fat percentage; However, data in Table 2. Significantly maximum ether extractable fat was recorded in cultivar Sargodha-2011 and it was followed by the cultivar Avon with ether extractable fat percentage. Statistically minimum ether extractable fat contents were recorded in cultivar PD2LV65. [31] also observed significant differences among the cultivars for ether extractable fat percentage. Seed inoculation significantly affected the ether extractable fat percentage in forage oat. The maximum ether extractable fat percentage was recorded where Azotobacter inoculation was applied and it was followed by Azospirillum with ether extractable fat percentage. Minimum ether extractable fat percentage was recorded in un-inoculated control treatment. It may be due to increase in nutrient availability that resulted in increase of fat content along with other quality parameters. These results are in line with those of [33] who reported a significant increase in fat contents of sunflower with application of bio-fertilizer.

\section{Conclusion}

It is concluded that cultivar Sargodha-2011 which was inoculated with Azotobacter spp. gave higher forage yield of good quality under Faisalabad conditions.

\section{References}

[1] Zaman, Q., Hussain, M.N., Aziz, A. and Hayat, K. (2006) Performance of High Yielding Oat Cultivars under AgroEcological Conditions of D. I. Khan. Journal of Agricultural Research, 44, $29-35$.

[2] Younas, M. and Yaqoob, M. (2005) Feed Resources of Livestock in the Punjab, Pakistan. Livestock Research for Rural Development, 17, Art. 18.

[3] Sial, M.A. and Aalam, M.Z. (2008) Livestock Feed Resources Scenario of Pakistan. Journal of Agricultural Research, 45, 199-203.

[4] Dost, M., Hussain, A., Khan, S. and Bhatti, M.B. (2004) Green Forage Yield, Dry Matter Yield and Chemical Composition of Oat with Advances in Maturity. Pakistan Journal of Scientific and Industrial Research, 37, 198-200.

[5] Douglas, C.D., Michael, A., Mullen, S.M.C. and James, J.H. (2001) Genotypic and Environmental Effects on Grain Yield and Quality of Oat Grown in North Dakota. Journalof Crop Science and Biotechnology, 41, 1066-1072.

[6] Haqqani, A.M., Ali, Z., Shafique, S., Zahid, S. and Baksh, A. (2003) Oat: A Forage of Winter Lean Period. Agric. Dig. Zari., 23, 15-23.

[7] Habib, G., Ahmad, T., Saba, I. and Akhter, N. (2003) Genotype Variation in the Yield and Nutritive Quality of Oat Forage. Sarhad Journal of Agriculture, 19, 419-422.

[8] Chohan, M.S.M., Nadeem, M., Khan, A.H. and Kainth, R.A. (2006) Performance of Pearl Millet (Pennisetumamericanum L.) Cultivars for Forage Yield. Journal of Agricultural Research, 44, $23-27$.

[9] Pedo, I., Sgarbieri, V.C. and Gutkoski, L.C. (2000) Protein Evaluation of Four Oat (Avena sativa L.) Cultivars Adapted for Cultivation in the South of Brazil. Plant Foods for Human Nutrition, 53, 297-304. http://dx.doi.org/10.1023/A:1008032013635

[10] Tien, H.H., Hien, T.M., Son, M.T. and Herridge, D. (2000) Rhizobial Inoculation and N2 Fixation of Soybean and Mungbean in the Eastern Region of South Vietnam. In: Herridge, D., Ed., Inoculants and Nitrogen Fixation of Legumes in Vietnam, ACIAR Proceedings, Canberra, 29-36.

[11] Ozturk, A., Caglarand, O. and Sahin, F. (2003) Yield Response of Wheat and Barley to Inoculation of Plant Growth Promoting Rhizobacteria at Various Levels of Nitrogen Fertilization. Journal of Plant Nutrition and Soil Science, 32, 166-266. http://dx.doi.org/10.1002/jpln.200390038

[12] Nowak, J. (2011) Review benefits of in Vitro Bacterization of Plant Tissue Culture with Microbial Inoculants. In Vitro Culture and Development Biology of Plant, 34, 122-123. http://dx.doi.org/10.1007/BF02822776

[13] Bhatti, M.B., Hussain, A. and Mohammad, D. (2002) Forage Production Potential of Different Oat Cultivars under Two Cut Systems. Pakistan Journal of Agricultural Research, 13, 184-190.

[14] Mahdi, S.S., Hassan, G.I., Samoon, H.A., Rather, A.D., Shoukat. and Zehra, B. (2010) Bio-Fertilizers in Organic Agriculture. Journalof Phytology, 2, 42-54.

[15] Catroux, G. (2001) Inoculant Quality Standards and Controls in France. Expert Consultation on Legume Inoculant 
Production and Quality Control, FAO, In. Thompson, J.A., Ed., FAO, Rome, 113-120.

[16] El-Lattief, E.A. (2012) Improving Bread Wheat Productivity and Reduce use of Mineral Nitrogen by Inoculation with Azotobacter and Azospirillum under Arid Environment in Upper Egypt. Int. Conf. App. Life Sci, 393-398.

[17] Belimov, Y., Holguin, G. and Bashan, L.E. (2004) Influence of Bacterial Inoculation in Upland Farming System of the Sikkim Himmalya. Soil Biology and Biochemistry, 30, 379-384.

[18] Asghar, H.N., Zahir, Z.A., Arshad, M. and Khaliq, A. (2002) Relationship Between in Vitro Production of Auxins by Rhizobacteria and their Growth Promoting Activities in Brassica juncea L. Biology and Fertility of Soils, 35, 231-237. http://dx.doi.org/10.1007/s00374-002-0462-8

[19] Toledo, M.V., Gozalez-Lopez, J., Moreno, J. and Ramos-Cormenzana, A. (2004) Effect of Inoculation with Azotobacter chroococcum on Nitrogenase Activity of (Zea mays L.) Roots Grown in Agricultural Soils under Aseptic and Non-Sterile Conditions. Biology and Fertility of Soils, 6, 170-173. http://dx.doi.org/10.1007/BF00257669

[20] Waseem-ul-hassan, S., Anees, S.M. and Bajoi, A.H. (2000) Evaluation of Oat Cultivars for High Yielding Green Forage under Environmental Conditions of Balochistan, Pakistan. Balochistan Journal of Agricultural Sciences, 1, 15-21.

[21] Abbasdokht, H. (2008) The Study of Azotobacter chroococum Inoculation on Yield and Post-harvest Quality of Wheat (Triticum aestivum L.). International Journal of Agriculture and Biology, 44, 885-889.

[22] Ayub, M., Nadeem, M.A., Tahir, M., Ghafoor, A., Ahmad, Z. and Naeem M. (2010) Comparative Studies on the Growth, Forage Yield and Quality of Sorghum (Sorghum bicolor L.) Cultivars under Irrigated Conditions of Faisalabad,Pakistan. Journal of Plant Sciences, 8, 94-97.

[23] Shaalan, M.N. (2005) Influence of Biofertilizer and Poultry Manure on Growth, Yield and Seed Quality of (Nigella sativa L.) Plants. Egyptian Journal of Agricultural Research, 83, 811-828.

[24] Zafar, N. (2009) Forage Growth, Yield and Quality Performance of Different Oat (Avena sativa L.) Cultivars under Agro-Ecological Conditions of Faisalabad, Pakistan.Journal of Animal and Plant Sciences, 22, 733-737.

[25] El-Zieny, O.A.H., El-Behari, U.A. and Zaky, M.H. (2001) Influence of bBiofertilizer on Growth, Yield and Fruit Quality of Tomato Grown under Plastic House. Journal of Agricultural Sciences, 26, 1749-1763.

[26] Piri, I. and Tavassoli, A. (2012) Determining the Best Management of Nitrogen Fertilizer Consumption and Harvest Time of Forage Yield of Pearl Millet (Pennisetum americanum L.) in Shirvan Region.AfricanJournal of Microbiology Research, 6, 2287-2293.

[27] El-Toukhy, S.A. and Abdel-Azeem, H.H. (2000) Response of Barley (Hordeum vulgare L.) to Biofertilization Technology. Annals Agricultural Sciences, 2, 539-559.

[28] Farboodi, M., Alizadeh, M., Faramarzi, A., Shahrokhi, S. and Ali, R. (2011) Azotobacter Inoculation, Nitrogen Fertilizer and Manure Levels Effects on Morphological Characteristics of Corn SC-647, in a Greenhouse Study. Int. Conf. Biol. Environ. Chem, Vol. 24, IACSIT Press, Singapore, 23-26.

[29] Mandal, S.R., Mukherjee, A.K. and Patra, B.C. (2000) Effect of Biofertilizer (Azotobacter) Inoculation on Forage Yield and Quality of Oat. Indian Journal of Agricultural Sciences, 4, 524-527.

[30] Haider, G. (2008) Effect of Different Sowing Techniques on Growth, Forage Yield and Quality of Four Oat (Avena sativa L.) Cultivars. Pakistan Journal of Agricultural Sciences, 9, 123-128.

[31] Sharma, K.C. (2009) Response of Oat (Avena sativa L.) to Azospirillum Inoculant at Different Levels of Nitrogen Application. Indian Journal Agricultural Sciences, 79, 823-827.

[32] Shehata, M.M. and El-Khawas, S.A. (2003) Effect of Two Biofertilizers on Growth Parameters, Yield Characters, Nitrogenous Components, Nucleic Acids Content, Minerals, Oil Content, Protein Profiles and DNA Banding Pattern of Sunflower Yield. Pakistan Journal of Biological Sciences, 6, 1257-1268. http://dx.doi.org/10.3923/pjbs.2003.1257.1268

[33] Ayub, M., Shehzad, M., Nadeem, M.A., Pervez, M., Naeem, M. and Sarwar, N. (2011) Comparative Study on Forage Yield and Quality of Different Oat (Avena sativa L.)Cultivars under Agro Ecological Conditions of Faisalabad, Pakistan. African Journal of Agricultural Research, 6, 3388-3391. 